\title{
ROLE OF THE HEPARIN-BINDING DOMAIN IN INTRACELLULAR TRAFFICKING OF SHB-EGF
}

\author{
O. I. KRYNINA ${ }^{凶}$, K. YU. MANOILOV, D. V. KOLYBO, S. V. KOMISARENKO \\ Palladin Institute of Biochemistry, National Academy of Sciences of Ukraine, Kyiv; \\ @e-mail: olyakrynina@gmail.com
}

Received: 11 July 2018; Accepted: 17 May 2019

\begin{abstract}
Heparin-binding EGF-like growth factor (HB-EGF) is a member of the epidermal growth factor family that was proven as a potent mitogen and chemoattractant. HB-EGF mediated EGFR activation is a key event in the stimulation of gene expression, cell migration and proliferation during both normal and pathogenic physiological processes. The main goal of this research was to reveal the role of the heparin-binding domain of HB-EGF in the ligand-receptor formation and its further internalization to the cytoplasm. We used fluorescently-labeled recombinant derivative of soluble $H B-E G F$ and its truncated form ( $S H B-E G F_{\triangle 84-100}$ ) with deletion of the heparin-binding domain. Firstly, the binding kinetics of two forms of sHB-EGF to its cell surface receptors was determined using flow cytometry. To determine how the absence of heparin-binding domain in the structure of HB-EGF affects its internalization, we analyzed the endocytosis process of EGFPsHB-EGF ${ }_{\Delta 84-106}$ and EGFP-sHB-EGF complexes by confocal microscopy. It was found that the full-size form of HB-EGF is characterized by a lower intensity of translocation to the cytoplasm in comparison to HBDdeleted form. Thus, differences in the trafficking of the full-size or truncated forms of sHB-EGF in the cell cytoplasm may reflect the mechanisms of extracellular matrix influence on the biological activity of $s H B-E G F$.
\end{abstract}

K e y w o rd s: heparin-binding EGF-like growth factor, epidermal growth factor receptor, endocytosis.

$\mathrm{H}$ eparin-binding EGF-like growth factor (HB-EGF) is a member of EGF-like growth factors family. Originally this protein was purified from conditioned media of U937 monocytic cell culture and can provoke 3T3 fibroblast cell proliferation [1]. Further studies revealed that HB-EGF plays an important role in various physiological processes such as blastocyst implantation [2] and can stimulate proliferation, migration and differentiation of keratinocytes [3-5], corneal epithelial cells [6], smooth muscle cells [7], hepatocytes [8] and other cells.

Like others EGF-like growth factors, HB-EGF is synthesized as a transmembrane precursor that can undergo proteolytic cleavage by metalloproteinases forming soluble HB-EGF (sHB-EGF) [9,10]. Both membrane-anchored and soluble forms of HB-EGF can interact with an ErbB receptor class 1 (Epidermal growth factor receptor, EGFR) and class 4 and cause receptor dimerization with subsequent activa- tion of several signaling pathways that determine functional response of a cell [11]. Binding of sHBEGF to EGFR leads to the formation of the ligandreceptor complex that is transported to the cytoplasm mainly via clathrin-mediated endocytosis [9]. Downstream EGFR trafficking after HB-EGF stimulation can be ended with lysosomal degradation of the receptor [12] or its nuclear localization where EGFR can interact with cyclin D1 promoter region [13].

Different ligands of EGFR vary in their ability to promote receptor intracellular transport and its endocytic sorting. HB-EGF and betacellulin both show the most efficient EGFR phosphorylation potency that highly correlates with the rates of EGFR degradation in lysosomes mediated by these growth factors [12]. Also, EGFR internalization after HB-EGF or betacellulin stimulation can occur even after clathrin silencing meaning that these proteins can utilize another mechanism of endocytosis [14].

(C) 2019 Krynina O. I. et al. This is an open-access article distributed under the terms of the Creative Commons Attribution License, which permits unrestricted use, distribution, and reproduction in any medium, provided the original author and source are credited. 
Interestingly, HB-EGF and betacellulin share the ability to interact with heparan sulfate proteoglycans (HSPGs) that play an important role in extracellular matrix formation and organization. HSPGs serve many purposes related to modulation and regulation of growth factors activity both in inhibition and stimulation directions. Functioning as reservoirs for chemoattractant cytokines they provide a quick response to disruption of skin by releasing agents that promote fibroblasts and keratinocytes migration during wound healing [15]. Interaction of transmembrane forms of growth factors with HSPGs in cell-cell contact sites can prevent its shedding and limit auto/paracrine receptor activation that leads to excessive cell proliferation [16]. HSPGs often act as co-receptors promoting a formation of a stable ligand-receptor complex and can regulate kinetics of signaling kinases phosphorylation.

Earlier in our laboratory, it was designed recombinant full-size and truncated (with the lack of heparin-binding domain) forms of HB-EGF that were fluorescently-labeled with mCherry or EGFP. These proteins both had a proliferative effect on fibroblast cells and retained their ability to bind to EGFR, making them perfect tools for investigation of intracellular transport mechanisms [17]. The main goal of this work was to reveal a role of heparinbinding domain of HB-EGF in the process of its binding to receptors and trafficking to the cytoplasm.

\section{Materials and Methods}

Materials and reagents. RPMI 1640 media with phenol red, sodium bicarbonate, bovine serum albumin (BSA), Moviol 4-88, 1,4-diazabicyclo[2.2.2] octan, 98\% and paraformaldehyde were obtained from Sigma Aldrich (USA). Penicillin G, streptomycin, chloramphenicol, kanamycin were from Arterium Co. (Ukraine). Eukaryotic cell culture $\varnothing 10 \mathrm{~cm}$ Petri dishes and 24-well plates were purchased from Greiner Bio One (Great Britain) and fetal bovine serum (FBS) was from Gibco (USA). LB media was from Carl Roth (Germany). Isopropyl $\beta$-D-1thiogalactopyranoside (IPTG), HisPur Ni-NTA resin and Pierce Protease inhibitor mini tablets were obtained from Thermo Scientific (USA).

Mammalian cell cultures. A431 cell line was obtained from the Bank of Cell Lines of R.E. Kavetsky Institute of Experimental Pathology, Oncology and Radiobiology, National Academy of Sciences of Ukraine, Kyiv. Cells were cultured in RPMI-1640 medium (Sigma) supplemented with 2 g/l sodium bicarbonate and $10 \%$ fetal bovine serum (FBS) with the addition of the antibiotic-antimycotic solution to prevent bacterial and fungal contamination.

Expression and purification of recombinant fluorescent derivatives of $s H B-E G F$. Obtaining genetic constructions coding fluorescently labeled and fused with His-tag full-size and truncated forms of sHB-EGF was described previously [17]. E. coli Rosetta BL21(DE3) strain transformed by appropriate genetic constructions was used for expression of recombinant EGFP-sHB-EGF and EGFP-sHB$\mathrm{EGF}_{\Delta 84-106}$ proteins. Briefly, bacterial cells were grown at $37^{\circ} \mathrm{C}$ in LB media to obtaining of optical density $\mathrm{OD}_{650} \approx 0,5$, then expression inductor IPTG was added in a final concentration of $1 \mathrm{mM}$. Then cells were incubated at $30{ }^{\circ} \mathrm{C}$ for 3 hours and pelleted by centrifugation. Cell pellets were resuspended in lysis buffer ( $50 \mathrm{mM}$ Tris-HCl, $250 \mathrm{mM} \mathrm{NaCl}$, $\mathrm{pH}$ 8.0, proteinase inhibitor cocktail) and lysed by sonification keeping cell suspension on ice to prevent undesirable degradation of fusion-proteins. Soluble EGFP-fused sHB-EGF derivatives were purified from cell lysate supernatants by column affinity chromatography on Ni-NTA agarose. After washing sorbent with 5 volumes of wash buffer $(50 \mathrm{mM}$ Tris$\mathrm{HCl}, 250 \mathrm{mM} \mathrm{NaCl}, 20 \mathrm{mM}$ imidazole, $\mathrm{pH}$ 8.0) proteins were eluted with $250 \mathrm{mM}$ imidazole. Purification efficiency and protein concentration were analyzed by tricine SDS-PAGE.

Flow cytometry. Adherent A431 cells were detached from the bottom of $10 \mathrm{~mm}$ Petri dishes by incubation in $30 \mathrm{mM}$ EDTA solution in PBS during $10 \mathrm{~min}$ at $37^{\circ} \mathrm{C}$. A total number of cells was calculated using hemocytometer and divided into 3 series of samples so that each contains approximately $0.2-0.5 \times 10^{6}$ cells. Each sample was washed and resuspended in 1\% BSA in PBS solution with the addition of $0.02 \% \mathrm{NaN}_{3}$ to prevent endocytosis process. To determine the rate of HB-EGF binding to plasma membrane proteins A431 cells were incubated with EGFP-sHB-EGF, EGFP-sHB-EGF ${ }_{\Delta 84-106}$ or EGFP (control protein) in appropriate equimolar concentrations for $40 \mathrm{~min}$ at $4{ }^{\circ} \mathrm{C}$. After the incubation was completed stained cells were washed and resuspended in $1 \mathrm{ml}$ of BSA/PBS solution.

Determination of cells fluorescence intensity was performed with Beckman Coulter Epic XL flow cytometer. For each sample emission was collected with Fl1 channel (515-535 nm). In a parallel forward and side scattered light was measured to track possible changes of cell morphology. To obtain correct 
mean of fluorescence parameter values $1 \times 10^{4}$ events were counted per sample. Obtained experimental data was analyzed with Flowing Software.

Confocal microscopy and image analysis. A431 cells were seeded on the $\varnothing 15 \mathrm{~mm}$ glass coverslips in 24 -well plate to obtain $80 \%$ confluency. On the next day, cells were washed with PBS several times and then fresh RPMI-1640 medium containing $100 \mathrm{nM}$ EGFP-sHB-EGF or EGFP-sHB-EGF ${ }_{\triangle 84-106}$ was added. A431 cells were incubated with fluorescent derivates of HB-EGF and 0,5 mM Hoechst 33342 for specified periods of time and fixed in $4 \%$ paraformaldehyde in PBS for $40 \mathrm{~min}$ at $4{ }^{\circ} \mathrm{C}$. Washed coverslips were mounted in Moviol-DABCO medium and stored at $4{ }^{\circ} \mathrm{C}$. Confocal microscopy experiments were performed by using Carl Zeiss LSM 510META instrument, with objective Plan-Apochromat 63x/1.4 Oil. Diode lasers with $488 \mathrm{~nm}$ and $405 \mathrm{~nm}$ wavelength were used for excitation of chromophores EGFP and Hoechst 33342 respectively.

Fiji image processing package was used to analyze confocal photos [18]. Images were manually thresholded to ensure contrasting endosomal mapping. To obtain the number and the average size of endosomes values the "Particle analysis" built-in tool was used with the cut-off of $0.2-2.5 \mu \mathrm{m}$.

\section{Results and Discussion}

Determination of binding kinetics of fluorescently labeled recombinant HB-EGF derivatives. To determine the ability of the sHB-EGF derivatives specifically interact with receptors on the cell surface we selected A431 cell line from human epidermis carcinoma origin. It is an ideal model for studying the biological effects of HB-EGF due to significant EGFR overexpression. The kinetic dependence of the interaction of full-length and HBDdeleted forms of sHB-EGF with its receptors was investigated using the flow cytometry.

A431 cells were stained with fluorescent derivatives of sHB-EGF at the increasing range of concentrations. Samples were incubated for 40 minutes, then unbound proteins were washed. The incubation was performed at $4{ }^{\circ} \mathrm{C}$ with the presence of $0.01 \%$ $\mathrm{NaN}_{3}$ to prevent EGFR endocytosis. Since the flow cytometer recognizes the labels both on the cell surface as well as in the cytoplasm, the internalization of EGFR could complicate the interpretation of results. To determine non-specific receptor binding series of control samples of A431 cells stained with free EGFP in the same range of concentrations was made. Autofluorescence control was performed by measuring the fluorescence intensity of unstained cells.

Since EGFP protein did not show a significant ability to bind to cell surface nonspecifically, it can be concluded that the interaction of EGFP-sHBEGF $_{\triangle 84-106}$ and EGFP-sHB-EGF with receptors was specific. According to the experimental data, the fluorescence intensity of cells stained with full-size sHB-EGF is twice as high as the fluorescence intensity of cells stained with HBD-deleted form of sHBEGF (Fig. 1). The difference in values may indicate a greater number of binding sites for EGFP-sHB-EGF, so their saturation comes at a higher protein concentration. This fact can be explained by the interaction of a full-length sHB-EGF form with both EGFR receptors via an EGF-like domain, as well as by binding to HSPGs, that are also present on a plasma membrane of eukaryotic cells.

Internalization dynamics of full-size and truncated forms of HB-EGF. To examine how the absence of heparin-binding domain in the structure of HB-EGF affects its intracellular transport dynamics we performed fluorescence microscopy study. A431 cells were treated with equimolar amounts of EGFPsHB-EGF or EGFP-sHB-EGF ${ }_{\triangle 84-106}$ for $30 \mathrm{~min}$ on $4{ }^{\circ} \mathrm{C}$ to allow protein binding to its receptors. Then cells were transferred to $37^{\circ} \mathrm{C}$, incubated for several time periods of time, washed and fixed. During sam-

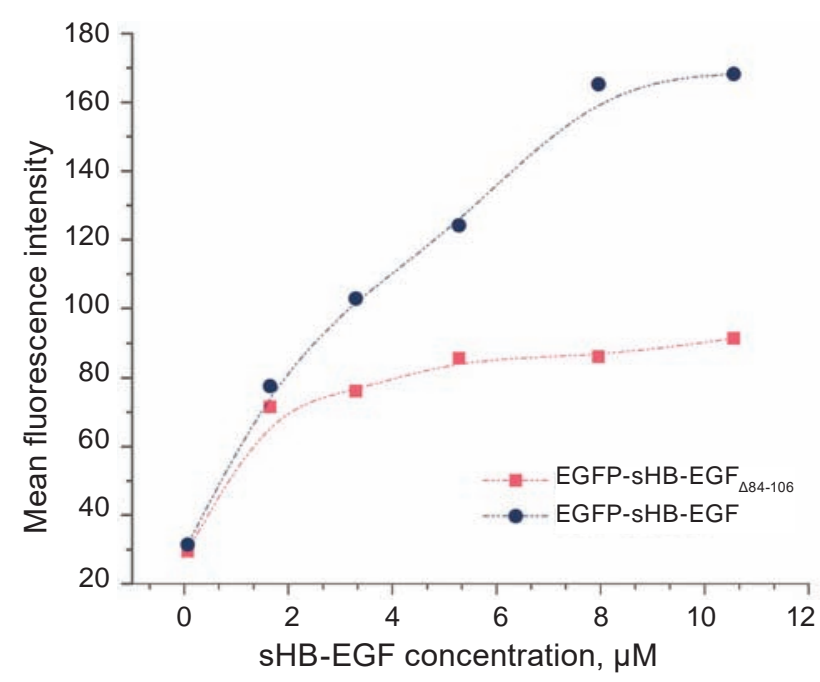

Fig. 1. Dependence of A431 cells fluorescence intensity on the staining concentration of recombinant EGFP-sHB-EGF ${ }_{484-106}$ and EGFP-sHB-EGF proteins. Points on the graph represent experimental data obtained with a flow cytometer 
ple examination by confocal microscopy, the binding efficiency of two forms of growth factor and the endosome formation were analyzed.

As can be seen from Fig. 2, after the first stage of EGFP-sHB-EGF and EGFP-sHB-EGF ${ }_{\Delta 84-106}$ incubation both proteins were bound to receptors on the cell membrane. Endocytic trafficking could be observed following 15 min of internalization in the form of bright green conglomerates. It should be noted, that the process of endocytosis was more intense for the HBD-deficient form of sHB-EGF comparing to the full-size form. The absence of the HBD-mediating interactions with HSPGs resulting in the more rapid absorption of the growth factor by cells could be the reason for the earlier internalization of the truncated form. After 15 min EGFP-sHBEGF and EGFP-sHB-EGF ${ }_{\triangle 84-106}$ were actively transported to the cell cytoplasm.

In more details, the process of endocytosis at each interval of time can be characterized by quantitative parameters that can be obtained after confocal images processing. The Fiji Image Processing program includes a variety of plug-ins designed to facilitate microscopy data analysis. With it, the total number of endosomes and the average size of endosomes parameters were calculated for each image.

Particle analysis on Fiji provided information about the number of endosomes in a transverse sec- tion of a single cell for each incubation time interval (Fig. 3, A). It is evident that the number of endosomes increases with time for both experimental proteins. The full-size form of sHB-EGF was internalized later and forms a smaller number of endosomes than EGFP-sHB-EGF ${ }_{\triangle 84-106}$ during the whole period of investigation. Since the studied proteins were taken at the same concentration, the difference in the number of endosomes could be explained by the more intensive translocation process of the truncated growth factor form. Another point is that the absence of HBD in the structure of sHB-EGF can adversely affect receptor-ligand complex stability in a highly acidic environment in maturating endosomes. In this case, ligand dissociation can mediate the recycling process, resulting in EGFR receptors returning to a cell surface while being able to internalize other molecules of sHB-EGF.

Fig. $3, B$ reflects the change in the average size of endosomes on the chosen time intervals. The obtained data indicate that the average endosomal size formed after EGFP-sHB-EGF ${ }_{\triangle 84-106}$ or EGFP-sHBEGF internalization almost does not differ. Also, for both forms of growth factor, the same dynamics of endosomal size increasing was observed with incubation time passing. Probably, we can partially observe the process of endosomal maturation. It can be assumed that the smallest vesicles in the cyto-
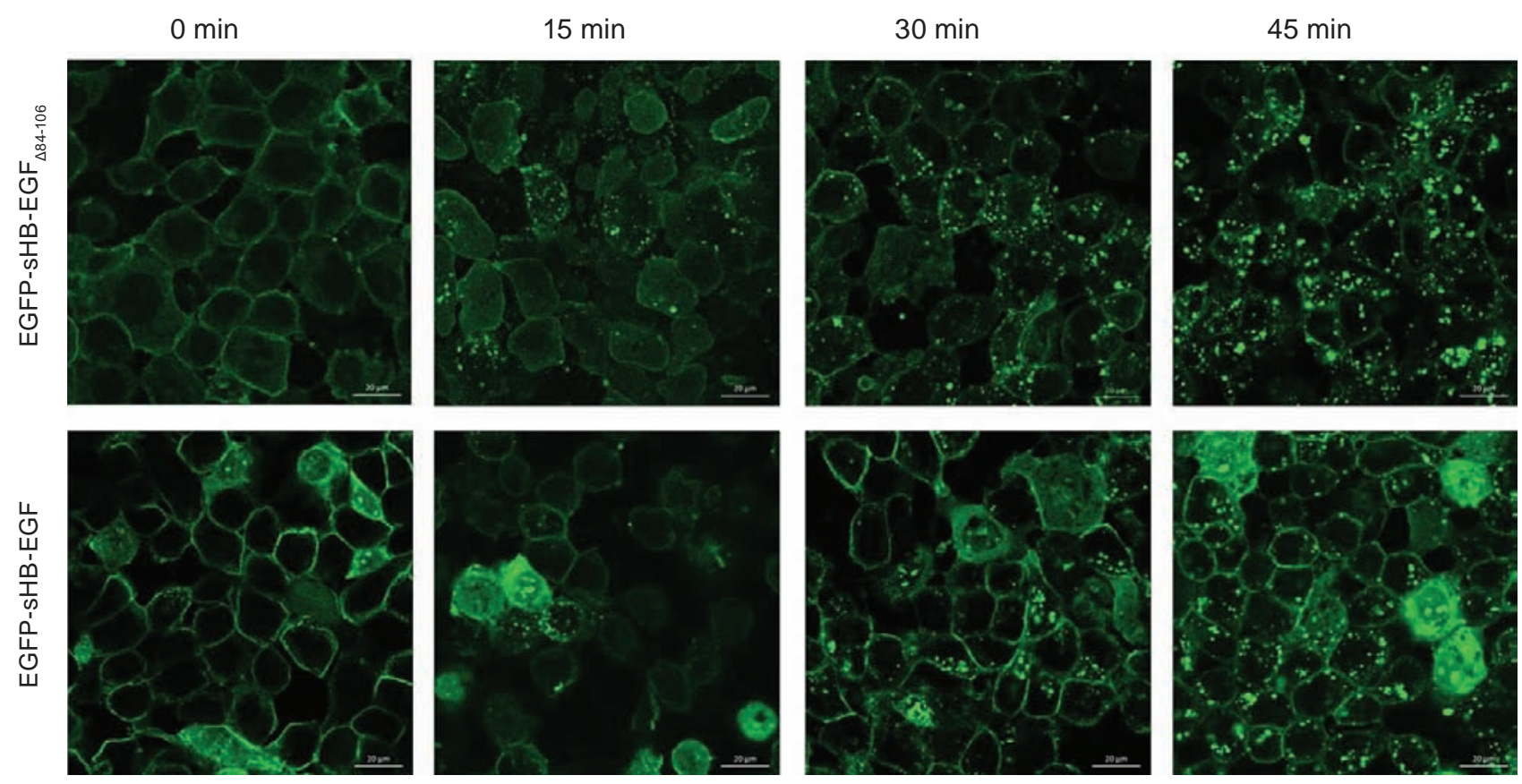

Fig. 2. Confocal images of the fixed A431 cell treated with recombinant EGFP-sHB-EGF and EGFP-sHB$E F_{486-104}$ proteins for several periods of time. Scale bar $20 \mu \mathrm{m}$ 
A

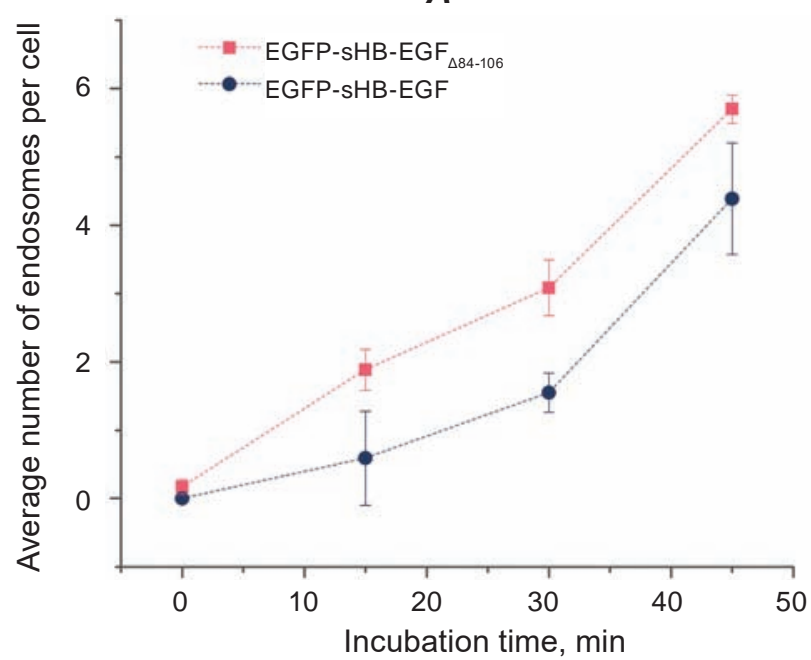

B

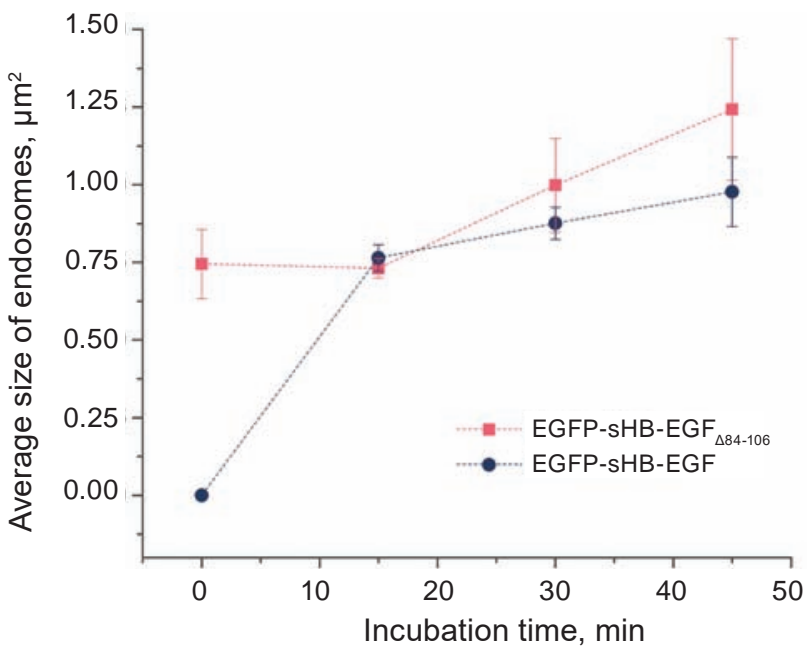

Fig. 3. Parameters that characterize EGFR endocytosis after A431 cells stimulation with equimolar concentration of EGFP-sHB-EGF and EGFP-sHB-EGF ${ }_{\triangle 84-106}$ obtained using particle analysis Fiji tool. $\boldsymbol{A}$ - Dynamics of changes in the endosome number on the transverse section of A431 cells; $\boldsymbol{B}$-Dynamics of changes in the average size of endosomes on the transverse section of A431 cells

plasm are early endosomes that can be seen at the first stages of sHB-EGF internalization. Following 30 min, individual small vesicles bearing a fluorescent label begin to merge with each other and form larger conglomerates - late endosomes.

In conclusion, in the present study, we used the full-sized and truncated forms of recombinant human sHB-EGF to investigate the role of a heparinbinding domain in the process of endocytic internalization of this growth factor by cells. The key finding is that sHB-EGF interaction with HPSGs on cell surface provokes prolongation of ligand-receptor complex formation that results in a delay of sHBEGF income into cells.

The differences in the internalization dynamics of full-size or shortened forms may contribute to subsequent sHB-EGF-dependent cellular responses. It is known that among various EGF-like growth factors, that able to induce EGFR phosphorylation, some differ in their ability to activate downstream signaling pathways. For example, betacellulin predominantly phosphorylates Y1068 residue EGFR that lead to more active recruitment of Grb2/MEKK1 and enhanced MEK/Erk activation, resulting in increased cell survival [19]. Another effect was shown for heparin binding fibroblast growth factor 2 (FGF). Its disrupted interaction with syndecan-4 that is one of HSPGs members drives to accelerated, enhanced and more persistent ERK phosphorylation [20]. Similarly, the heparin-binding domain of HB-EGF and the rapidity of formation its stable complex with EGFR may play a defining role in appropriate EGFR phosphorylation and activation of different signaling pathways. Thus, HB-EGF interaction with HSPGs can be very important for proper cellular response and maintenance of activity of this growth factor.

Conflict of interest. Authors have completed the Unified Conflicts of Interest form at http:// ukrbiochemjournal.org/wp-content/uploads/2018/12/ coi_disclosure.pdf and declare no conflict of interest.

\section{РОЛЬ ГЕПАРИНЗВ'ЯЗУВАЛЬНОГО ДОМЕНУ У ВНУТРІШНЬО- КЛІТИННОМУ ТРАФІКУ SНВ-EGF}

\author{
О. І. Криніна ${ }^{凶}$, К. Ю. Манойлов, \\ Д. В. Колибо, С. В. Комісаренко
Інститут біохімії ім. О. В. Палладіна НАН України, Київ; 凶e-mail: olyakrynina@gmail.com

Гепаринзв'язувальний EGF-подібний фактор росту (HB-EGF) $€$ представником сімейства епідермальних факторів росту, який $€$ потужним мітогеном та атрактантом. HB-EGFопосередкована активація EGFR $є$ необхідною для стимуляції експресії генів, міграції та проліферації клітин як за нормальних, так і патогенних фізіологічних процесів. Основна мета 
цього дослідження полягала у визначенні ролі гепаринзв'язувального домену HB-EGF у процесі формування стабільного рецептор-лігандного комплексу та його подальшої інтерналізації до цитоплазми. Було використано флуоресцентномічене рекомбінантне похідне розчинного НBEGF та його вкорочену форму ( $\left.\mathrm{sHB}^{-E_{\mathrm{GF}}}{ }_{\Delta 84-106}\right)$ 3 делецією гепаринзв'язувального домену. Спочатку, з використанням протокової цитофлуориметрії, було визначено кінетику зв'язування двох форм sHB-EGF до його рецепторів на поверхні клітин. Для дослідження впливу відсутності гепаринзв'язувального домену в структурі HB-EGF на його інтерналізацію проаналізовано процес ендоцитозу EGFP-sHB-EGF ${ }_{\Delta 84-106}$ та EGFP-sHB-EGF за допомогою конфокальної мікроскопії. Виявлено, що повнорозмірна форма HB-EGF характеризується меншою інтенсивністю транслокації до цитоплазми порівняно з вкороченою формою sHB-EGF. Таким чином, відмінності у транспортуванні повнорозмірної або вкороченої форми SHB-EGF до клітинної цитоплазми можуть відображати механізми впливу позаклітинного матриксу на прояв біологічної активності sHB-EGF.

К л ю ч о в і с л о в а: гепаринзв'язувальний EGF-подібний фактор росту, рецептор епідермального фактора росту, ендоцитоз.

\section{References}

1. Higashiyama S, Abraham JA, Miller J, Fiddes JC, Klagsbrun M. A heparin-binding growth factor secreted by macrophage-like cells that is related to EGF. Science. 1991; 251(4996): 936-939.

2. Miyazono K. Ectodomain shedding of HB-EGF: a potential target for cancer therapy. J Biochem. 2012; 151(1): 1-3.

3. Hashimoto K, Higashiyama S, Asada $H$, Hashimura E, Kobayashi T, Sudo K, Nakagawa T, Damm D, Yoshikawa K, Taniguchi N. Heparinbinding epidermal growth factor-like growth factor is an autocrine growth factor for human keratinocytes. J Biol Chem. 1994; 269(31): 20060-20066.

4. Tokumaru S, Higashiyama S, Endo T, Nakagawa T, Miyagawa JI, Yamamori K, Hanakawa Y, Ohmoto H, Yoshino K, Shirakata Y, Matsuzawa Y, Hashimoto K, Taniguchi N. Ectodomain shedding of epidermal growth factor receptor ligands is required for keratinocyte migration in cutaneous wound healing. J Cell Biol. 2000; 151(2): 209-220.

5. Shirakata Y, Kimura R, Nanba D, Iwamoto R, Tokumaru S, Morimoto C, Yokota K, Nakamura M, Sayama K, Mekada E, Higashiyama S, Hashimoto K. Heparin-binding EGF-like growth factor accelerates keratinocyte migration and skin wound healing. J Cell Sci. 2005; 118(Pt 11): 2363-2370.

6. Xu KP, Ding Y, Ling J, Dong Z, Yu FS. Woundinduced HB-EGF ectodomain shedding and EGFR activation in corneal epithelial cells. Invest Ophthalmol Vis Sci. 2004; 45(3): 813-820.

7. Bakken AM, Protack CD, Roztocil E, Nicholl SM, Davies MG. Cell migration in response to the amino-terminal fragment of urokinase requires epidermal growth factor receptor activation through an ADAM-mediated mechanism. J Vasc Surg. 2009; 49(5): 1296-1303.

8. Zhang D, Zhang J, Jiang X, Li X, Wang Y, Ma J, Jiang $\mathrm{H}$. Heparin-binding epidermal growth factor-like growth factor: a hepatic stellate cell proliferation inducer via ErbB receptors. J Gastroenterol Hepatol. 2014; 29(3): 623-632.

9. Sahin U, Weskamp G, Kelly K, Zhou HM, Higashiyama S, Peschon J, Hartmann D, Saftig P, Blobel CP. Distinct roles for ADAM10 and ADAM17 in ectodomain shedding of six EGFR ligands. J Cell Biol. 2004; 164(5): 769779.

10. Higashiyama S, Iwabuki $\mathrm{H}$, Morimoto C, Hieda M, Inoue $\mathrm{H}$, Matsushita N. Membraneanchored growth factors, the epidermal growth factor family: beyond receptor ligands. Cancer Sci. 2008; 99(2): 214-220.

11. Holbro T, Civenni G, Hynes NE. The ErbB receptors and their role in cancer progression. Exp Cell Res. 2003; 284(1): 99-110.

12. Roepstorff K, Grandal MV, Henriksen L, Knudsen SL, Lerdrup M, Grøvdal L, Willumsen BM, van Deurs B. Differential effects of EGFR ligands on endocytic sorting of the receptor. Traffic. 2009; 10(8): 1115-1127.

13. Korotkevych NV, Labyntsev AJ, Kolybo DV, Komisarenko SV. The Soluble Heparin-Binding EGF-Like Growth Factor Stimulates EGF Receptor Trafficking to the Nucleus. PLoS One. 2015; 10(5): e0127887.

14. Henriksen L, Grandal MV, Knudsen SL, van Deurs B, Grøvdal LM. Internalization 
mechanisms of the epidermal growth factor receptor after activation with different ligands. PLoS One. 2013; 8(3): e58148.

15. Bishop JR, Schuksz M, Esko JD. Heparan sulphate proteoglycans fine-tune mammalian physiology. Nature. 2007; 446(7139): 1030-1037.

16. Prince RN, Schreiter ER, Zou P, Wiley HS, Ting AY, Lee RT, Lauffenburger DA. The heparin-binding domain of HB-EGF mediates localization to sites of cell-cell contact and prevents HB-EGF proteolytic release. J Cell Sci. 2010; 123(Pt 13): 2308-2318.

17. Korotkevych NV, Labyntsev AJ, Kolybo DV, Komisarenko SV. Obtaining and characterization of recombinant fluorescent derivatives of soluble human HB-EGF. Biotechnol Acta. 2014; 7(2): 46-53.
18. Schindelin J, Arganda-Carreras I, Frise E, Kaynig V, Longair M, Pietzsch T, Preibisch S, Rueden C, Saalfeld S, Schmid B, Tinevez JY, White DJ, Hartenstein V, Eliceiri K, Tomancak P, Cardona A. Fiji: an open-source platform for biological-image analysis. Nat Methods. 2012; 9(7): 676-682.

19. Saito T, Okada S, Ohshima K, Yamada E, Sato M, Uehara Y, Shimizu H, Pessin JE, Mori M. Differential activation of epidermal growth factor (EGF) receptor downstream signaling pathways by betacellulin and EGF. Endocrinology. 2004; 145(9): 4232-4243.

20. Elfenbein A, Lanahan A, Zhou TX, Yamasaki A, Tkachenko E, Matsuda M, Simons M. Syndecan 4 regulates FGFR1 signaling in endothelial cells by directing macropinocytosis. Sci Signal. 2012; 5(223): ra36. 